\title{
Eating Disorders and Female Sexuality: Current Evidence-base and Future Implications
}

\author{
Carolina Leonidas ${ }^{7}$ \\ Manoel Antônio dos Santos \\ ${ }^{1}$ Universidade Federal do Triângulo Mineiro \\ ${ }^{2}$ Universidade de São Paulo
}

\begin{abstract}
This study aimed to examine current scientific production regarding sexuality-related issues in the context of eating disorders (ED). Searches were performed on PubMed, LILACS, CINAHL and PsycINFO, including papers published between 2008 and 2018, using the following descriptors: eating disorders, femininity, sexuality and sexual behavior. Nineteen studies were selected. Findings were systematized into two main thematic categories and showed, in general, that femininity can be a risk factor to the development of ED. Studies indicated that endorsing a gender role that is socially considered discrepant from biological sex, despite feminine or masculine, is related to ED symptomatology. Moreover, body dissatisfaction is positively correlated to sexual dysfunction. Interventions targeting prevention of ED should include sexuality-related issues by approaching probable negative consequences of adhering to female gender role social requirements and stereotypes, especially those related to body weight and body shape.

Keywords: eating disorders; sexuality; femininity
\end{abstract}

Transtornos Alimentares e Sexualidade Feminina: Evidências Atuais e Implicações Futuras

\section{Resumo}

O estudo buscou examinar a produção científica atual acerca de questões relacionadas à sexualidade no contexto dos transtornos alimentares (TAs). As buscas foram realizadas nas bases de dados PubMed, LILACS, CINAHL e PsycINFO, incluindo artigos publicados entre 2008 e 2018, com os seguintes descritores: transtornos alimentares, feminilidade, sexualidade e comportamento sexual. Dezenove estudos foram selecionados. Os dados foram sistematizados em duas categorias principais e demonstraram, de maneira geral, que a feminilidade pode ser considerada como fator de risco para o desenvolvimento de TAs. Os estudos indicaram que assumir um papel de gênero socialmente considerado discrepante do sexo biológico, independentemente de se tratar do gênero feminino ou masculino, está relacionado com sintomatologia de TAs. Além disso, a insatisfação com a imagem corporal mostra-se positivamente correlacionada com disfunção sexual. Enfatiza-se a necessidade de incluir questões relacionadas à sexualidade em intervenções direcionadas à prevenção de TAs, abordando as possíveis consequências negativas de se aderir aos estereótipos e requisitos sociais típicos do gênero feminino, especialmente aqueles relacionados ao peso e à forma corporal.

Palavras-chave: transtornos alimentares, sexualidade, feminilidade

\section{Trastornos Alimenticios y Sexualidad Femenina: Evidencias Actuales e Implicaciones Futuras}

\begin{abstract}
Resumen
El estudio buscó examinar la actual producción científica sobre los asuntos relacionados a la sexualidad en el contexto de los trastornos alimenticios (TAs). La búsqueda fue realizada en las bases de datos PubMed, LILACS, CINAHL y PsycINFO, incluyendo artículos publicados entre 2008 y 2018, con los siguientes descriptores: trastornos alimenticios, feminidad, sexualidad y comportamiento sexual. Diecinueve estudios fueron seleccionados. Los datos fueron sistematizados en dos categorías principales y demostraron, de manera general, que la feminidad puede ser considerada como un factor de riesgo para el desarrollo de TAs. Los estudios indicaron que asumir un rol de género socialmente considerado discrepante del sexo biológico, independientemente de si se trata del género femenino o masculino, está relacionado con la sintomatología de TAs. Además, la insatisfacción con la imagen corporal se muestra positivamente correlacionada con la disfunción sexual. Se enfatiza la necesidad de incluir temas relacionados a sexualidad, en intervenciones direccionadas a la prevención de TAs, abordando las posibles consecuencias negativas de adherirse a los estereotipos y requisitos sociales típicos del género femenino, especialmente aquellos relacionados a peso y forma corporal.

Palabras clave: trastornos alimenticios; sexualidad; feminidad
\end{abstract}

\section{Introduction}

Eating disorders (ED) are severe psychiatric conditions characterized mainly by dysfunctional eating behaviours and body image distortion (American
Psychiatric Association, 2013). Most of the individuals affected are young women in Western countries, which indicates the irrefutable presence of sexualityrelated issues in the aetiology of ED (Eddy, Novotny, \& Westen, 2004). Smink, Hoeken and Hoek (2013) 
state that although studies regarding incidence of ED on community level are scarce, the broad occurrence of anorexia nervosa (AN) among women might be up to $4 \%$, and $2 \%$ for bulimia nervosa $(\mathrm{BN})$ and binge eating disorder (BED).

Sexuality constitutes a multidimensional construct that involves more than sexual activities: it is also a connection between one's psychic and affective life, including relationships, feelings, fantasies and desires. This definition of sexuality departs from a broad conception proposed by the World Health Organization (2006), which comprehends this construct as a central aspect of human existence, encompassing sex, sexual health, sexual orientation, gender identities and roles, pleasure, eroticism, intimacy and reproduction. Several factors are entrenched in this definition: biological, psychological, social, cultural, religious, among others. Considering this wider conception of sexuality, it clarifies that the way women experience their own bodies affects their self-perception in a broader way, including openness to intimacy, social and romantic relationships, sexual functioning and health-related issues - eating behaviours comprised.

We must establish an important caveat. In the definition of common sense the category "women" covers people who have received such designation of gender identity at birth in accordance with their female genitalia. However, in line with Queer studies perspective (Butler, 2011), not all women have a female biological body (or sex), as in the case of transsexual women. Thus, it is possible to affirm that body image and the consequent experience of femininity can both develop independently of the biological body. In addition, we emphasize that "femininity" should be addressed in its plural form ("femininities"), since it addresses intersections between sex, gender, race/ethnicity, religion, social classes, among others. Finally, body image plays crucial role in sexual experiences and sexual relations, especially for women (Alba \& Kes, 2013).

Body image is widely known to be severely and negatively distorted in cases of ED, especially to women with $\mathrm{AN}$, constituting one of its main diagnostic criteria (American Psychiatric Association, 2013). Therefore, it is not surprising that women with AN present difficulties to express themselves sexually, or even to develop intimate relationships, remaining isolated, anxious and emotionally withdrawn. However, for women with $\mathrm{BN}$, both the relationship with food and the affectivesexual relationships are usually mediated by impulsive behaviours (Leonidas \& Santos, 2015a), which are common traits among these women, along with comorbidity with Borderline Personality Disorder (Rosa \& Santos, 2011). This shows that sexuality, as a multidimensional construct, is also influenced by personality traits.

Although literature has been recognizing the influence of body image on sexuality of healthy women (Woertman \& van den Brink, 2012), these variables remain vaguely investigated in the field of ED. Sexuality is only included in protocols of treatment for ED when related to history of sexual abuse and trauma (Carter et al., 2006). Also, contemporary research has shown higher levels of body image dissatisfaction, drive for thinness and disordered eating among sexual minorities than controls (Katz-Wise et al., 2014), which enhances the clear relationship between sexuality and ED symptomatology.

Considering the above, this study aimed to examine current scientific production regarding sexuality-related issues in the context of eating disorders (ED). Besides, we also aimed to expand understandings about the influence of sexuality on onset and maintenance of these disorders and guide future research in the area.

\section{Method}

This is an integrative review of the literature that enables the incorporation of scientific evidence to clinical practice. This type of literature review is the broadest and permits the inclusion of primary studies with different research designs. Also, authors are able to search, critically evaluate and summarise the available evidence, thus achieving the current status of knowledge on the subject of interest (Whittemore \& Knafl 2005).

\section{Search strategy}

The research question guiding this integrative review was "What is the available scientific evidence on possible associations between sexuality-related issues and the symptoms of ED'?

In order to clarify the components that guided the search for evidence, the research was based on the PICO strategy - Participants (P), Interventions (I), Comparisons (C) and Outcomes (O) (Akobeng, 2005; Cesnik \& Santos, 2012; Santos, Pimenta, \& Nobre, 2007; Stillwell, Fineout-Overholt, Melnyk, \& Williamson, 2010), as follows: "In individuals diagnosed with ED (P), evaluated through the application of standard 
scales, questionnaires and semi-structured interviews (I), how the symptoms of ED are associated to their experience of sexuality and femininity $(\mathrm{O})$, in comparison with normal population (C)?”

We followed the steps recommended by the PRISMA Statement - Preferred Reporting Items for Systematic Reviews and Meta-Analyses (Moher et al., 2009), namely: (1) systematic survey of international publications on the subject of sexuality and ED; (2) identification of the authors, methodological characteristics of each study, year, publishing journal, country of origin, language in which they were written, objectives and obtained results; and (3) conducting descriptive analysis of the results of the selected studies and critical evaluation of the contributions offered by the available scientific literature on the subject. Next, information regarding eligibility criteria, information sources, search strategy and study selection will be provided, according to PRISMA checklist (Moher et al., 2009).

Consulted databases were: PubMed (Medical Publications), CINAHL (Nursing and Allied Health Literature), PsycINFO (American Psychological Association, literature in behavioural sciences and mental health) and LILACS (Publications from Latin America and the Caribbean). The following descriptors were selected, according to DeCS - Health Sciences Descriptors and MeSH - Medical Subject Headings, combined with the boolean operator "and": eating disorders, femininity, sexuality and sexual behaviour. The search using the aforementioned descriptors was performed in March 2018.

The inclusion criteria for the primary studies were those addressing sexuality-related issues in the context of ED published between January 2008 and March 2018, with the following classifications: experimental studies, including randomized controlled clinical trials; cohort study; case-control study; quasi-experimental studies; non-experimental/cross-sectional studies; studies using qualitative approaches. Studies published in Portuguese, English and Spanish were selected. Therefore, the evidence levels (EL) 2, 3 and 4 were considered (Melnyc \& Fineout-Overholt, 2005). The established exclusion criteria were studies published in formats other than peer-reviewed articles, and articles addressing different topics from the scope of the present study. Duplicated studies were computed only once. Articles' methodological design was defined based on the criteria proposed by Sousa, Pimenta and Nobre (2007). Searches were performed by three researchers with experience in applying the procedure.

\section{Data abstraction and synthesis}

The flowchart (Figure 1) describes the identification route, selection and inclusion of selected primary studies. For data extracting, selected articles were retrieved in full and subjected to an analytical reading. Aiming to define the eligibility of each study, selected articles were independently and carefully read by the three qualified researches (judges) previously mentioned. The level of inter-judge concordance was calculated using the formula: agreement $=\Sigma$ possible concordance subtracted from real discordance divided by the number of articles (Machado et al., 2012). To ensure the reliability of classification, the results that obtained consensus between the three evaluators were accepted automatically. The discordant items were discussed individually until evaluators came to mutual agreement.

Figure 1 shows the review process. Initially, 579 articles were retrieved. After checking for duplication, 467 were screened and 104 were excluded based on inclusion and exclusion criteria previously described. Next, 363 full-text articles were assessed for eligibility, and 344 were excluded for addressing other thematics. Finally, 19 full-text articles composed this review.

Selected articles were qualitatively analysed through thematic categorization (Braun \& Clarke, 2006) and will be presented in the Discussion section. Categories were defined through convergence of themes. Articles do not appear in more than one category.

\section{Results}

The search resulted in 19 publications, constituting the corpus of analysis. As presented in Table 1, most of the studies were non-experimental, descriptive and correlational, with evidence level $4(\mathrm{n}=13)$, and six were quasi-experimental, with evidence level 3. No studies with experimental designs that fulfilled the inclusion criteria were found. However, the instruments used were mostly standardized and with important psychometric properties, thus there is substantial possibility of replicability, representing significant contribution to scientific literature in the field of ED. As for the origin of the studies, all were published in English and in international journals.

Most of the selected studies were published in $2017(n=5)$ and $2016(n=5)$; two were published in 2014 and three in 2013. There were no studies published in 2018, 2015 and 2009 that met inclusion criteria. Finally, there was one selected study published in each 

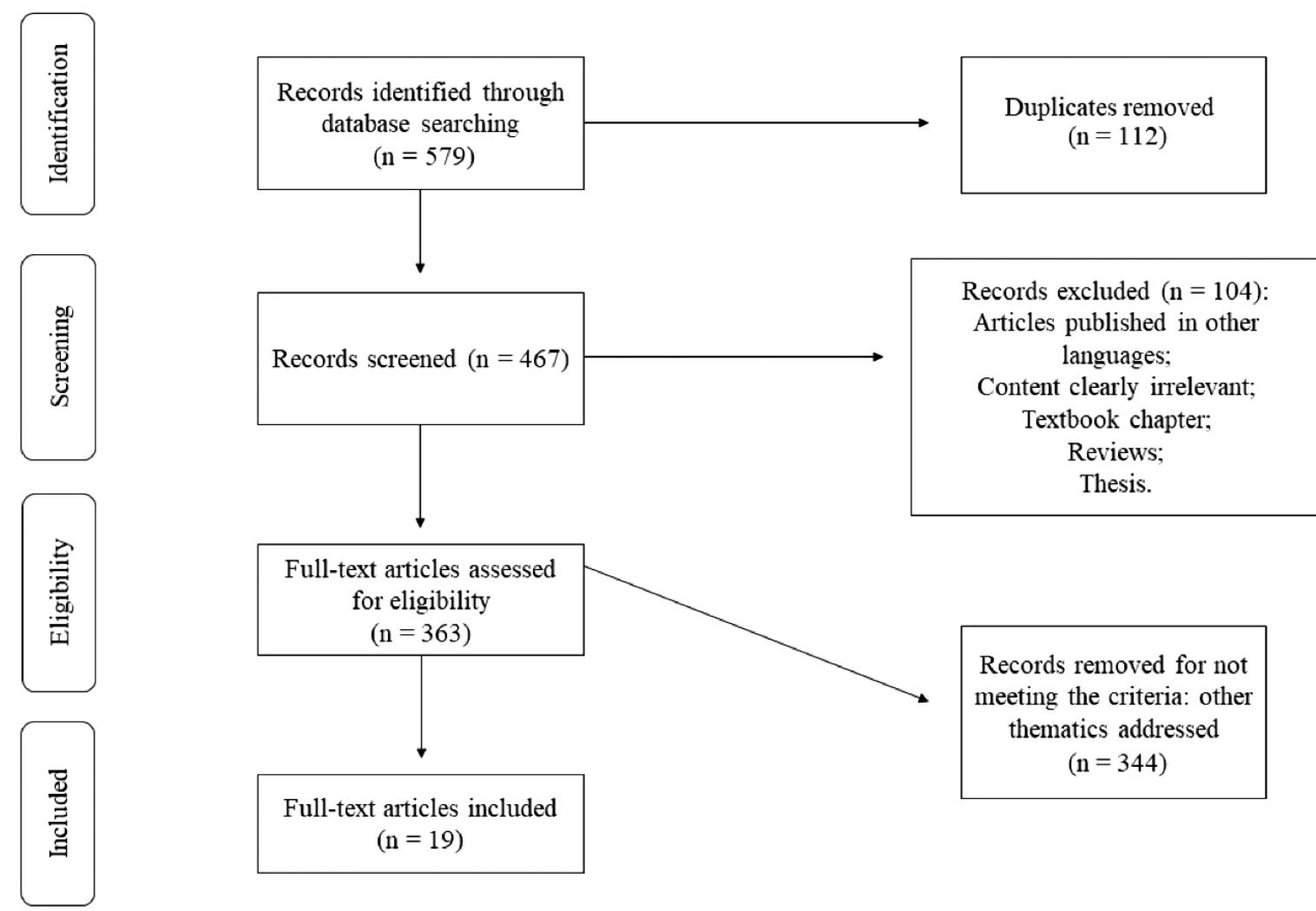

Full-text articles included $(\mathrm{n}=19)$

Figure 1. Flowchart of the review process based on the PRISMA model (Moher et al., 2009).

remaining year. Noticeably, the number of researches approaching sexuality-related issues in the context of ED has increased in the last three years.

Information regarding studies' objectives and main results will be presented in the Discussion section.

\section{Discussion}

Data presented by selected studies were grouped into two thematic categories (Braun \& Clarke, 2006), as follows, according to the convergence of themes.

\section{Gender role, female sociocultural standards and ED}

This category includes 11 studies that addressed gender roles and sexual behaviour in the context of ED, starting from the premise that gender role - i.e. how an individual stands in the world, within male and/or female dimensions - offers more in depth explanations to disordered eating behaviors rather than biological sex. These premises are based on those described by John Gagnon and William Simon in their sexual script theory (Gagnon \& Simon, 1973), which proposes human sexuality as consequence of the interaction between three levels of scripting: cultural, social and intrapsychic. In this way, sexual script theory relativizes the biological domain and broadens the understanding of human sexuality (Wiederman, 2005).

Six studies overall indicated that femininity was associated to eating pathologies, and therefore configured a risk factor for the development of ED (Cella, Iannaccone, \& Cotrufo, 2013; Mason, Lewis, \& Heron, 2017; Matthews-Ewald, Zullig, \& Ward, 2014; Lampis et al., 2017; Watson et al., 2017; Yean et al., 2013). These studies started from definitions of femininity and masculinity recommended by the Bem Sex Role Inventory (BSRI), which is a widely used self-administered instrument for measuring gender role identification. It entails that socially desirable feminine characteristics are: affectionate, loyal, eager to soothe hurtful feelings, soft spoken and tactful. On the contrast, socially desirable masculine characteristics involve: independent, makes decisions easily, willing to take risks, acts as a leader and competitive. It is worth emphasizing the need for updating these definitions, due to existing social movements on behalf of gender equality (Butler, 2011; Wiederman, 2005). We consider that self-defined, non-essentialist 
Table 1.

Characterization of retrieved articles according to authors, year of publication, study design, evidence level (EL), population and measures $(n=19)$.

\begin{tabular}{|c|c|c|c|}
\hline $\begin{array}{c}\text { Authors and year } \\
\text { of publication }\end{array}$ & $\begin{array}{c}\text { Study design and } \\
\text { EL }\end{array}$ & Population & Measures \\
\hline Green et al., (2008) & $\begin{array}{l}\text { Non-experimental, } \\
\text { descriptive, } \\
\text { correlational (EL 4) }\end{array}$ & $\begin{array}{l}86 \text { female college } \\
\text { students aged } 17-23\end{array}$ & $\begin{array}{l}\text { Eating Disorder Examination-Questionnaire } \\
\text { (EDE-Q) and Conformity to Feminine Norms } \\
\text { Inventory (CFNI). }\end{array}$ \\
\hline $\begin{array}{l}\text { Pinheiro et al., } \\
(2010)\end{array}$ & $\begin{array}{l}\text { Quasi experimental } \\
\text { (EL 3) }\end{array}$ & $\begin{array}{l}242 \text { women from } \\
\text { the multisite } \\
\text { international } \\
\text { Price Foundation } \\
\text { Genetic Studies of } \\
\text { Eating Disorders: } \\
\text { AN } \\
\text { Affected Relative } \\
\text { Pair Studies }\end{array}$ & $\begin{array}{l}\text { Structured Interview for Anorexic and } \\
\text { Bulimic Disorders-Psychopathology (SIAB-P), } \\
\text { Temperament and Character Inventory (TCI), } \\
\text { Frost Multidimentional Perfectionism Scale } \\
\text { (MPS), State-Trait Anxiety Inventory (STAI) } \\
\text { and Eating Disorder Inventory-2 (EDI-2). }\end{array}$ \\
\hline $\begin{array}{l}\text { Capitaine, Rodgers, } \\
\text { \& Chabrol (2011) }\end{array}$ & $\begin{array}{l}\text { Non-experimental, } \\
\text { descriptive, } \\
\text { correlational (EL 4) }\end{array}$ & 122 college women & $\begin{array}{l}\text { Eating Attitudes Test-26 (EAT-26), Centre for } \\
\text { Epidemiological Studies - Depression Scale } \\
\text { (CES-D), Sexual Experience Survey (SES) e } \\
\text { Visual Analog Scale (VAS). }\end{array}$ \\
\hline $\begin{array}{l}\text { Woolhouse et al., } \\
(2012)\end{array}$ & $\begin{array}{l}\text { Non-experimental, } \\
\text { descriptive, } \\
\text { correlational (EL 4) }\end{array}$ & $\begin{array}{l}37 \text { young women } \\
\text { aged } 11-19\end{array}$ & Semi-structured interview. \\
\hline $\begin{array}{l}\text { Castellini et al., } \\
\text { (2013) }\end{array}$ & $\begin{array}{l}\text { Quasi experimental, } \\
\text { longitudinal (EL 3) }\end{array}$ & $\begin{array}{l}27 \text { patients with } \\
\text { AN and } 31 \text { with } \\
\text { BN were assessed } \\
\text { at baseline and at } \\
1 \text {-year follow-up }\end{array}$ & $\begin{array}{l}\text { Structured Clinical Interview for Diagnostic } \\
\text { and Statistical Manual of Mental Disorders } \\
\text { IV (SCI - DSM-IV), Female Sexual Function } \\
\text { Index (FSFI), Eating Disorder Examination } \\
\text { Questionnaire (EDEQ), Beck Depression } \\
\text { Inventory (BDI), Spielberg's State-Trait } \\
\text { Anxiety Inventory (SSTAI), Symptom } \\
\text { Checklist-90 and Childhood Experience of } \\
\text { Care and Abuse Questionnaire (CECAQ). }\end{array}$ \\
\hline $\begin{array}{l}\text { Cella, Iannaccone, } \\
\text { \& Cotrufo (2013) }\end{array}$ & $\begin{array}{l}\text { Non-experimental, } \\
\text { descriptive, } \\
\text { correlational (EL 4) }\end{array}$ & $\begin{array}{l}132 \text { homosexuals, } \\
178 \text { heterosexuals } \\
\text { and } 15 \text { transexuals } \\
\text { (man to woman) }\end{array}$ & $\begin{array}{l}\text { Sociodemographic script, Eating Disorders } \\
\text { Inventory }-2 \text { (EDI-2), Body Uneasiness Test } \\
\text { (BUT) and Bem Sex Role Inventory (BSRI). }\end{array}$ \\
\hline Yean et al., (2013) & $\begin{array}{l}\text { Non-experimental, } \\
\text { descriptive, } \\
\text { correlational (EL 4) }\end{array}$ & $\begin{array}{l}506 \text { college } \\
\text { students and } 187 \\
\text { people from the } \\
\text { community ( } 246 \\
\text { men and } 447 \\
\text { women) }\end{array}$ & $\begin{array}{l}\text { Kinsey Heterosexual-Homosexual Likert- } \\
\text { type Scale, Body Shape Questionnaire } \\
\text { (BSQ), Eating Attitudes Test-26 (EAT-26), } \\
\text { Drive for Thinness subscale of the Eating } \\
\text { Disorder Inventory-II (DFT, EDI-II), Drive } \\
\text { for Muscularity Scale (DFM), Rosenberg } \\
\text { Self-Esteem Scale (RSES) and Sociocultural } \\
\text { Attitudes Towards Appearance Scale-3 } \\
\text { (SATAQ). }\end{array}$ \\
\hline
\end{tabular}


Table 1.

Characterization of retrieved articles according to authors, year of publication, study design, evidence level (EL), population and measures $(n=19)$. (Continuation)

Collins et al., $\quad$ Non-experimental, 319 female college (2014)

Eating Disorder Examination Questionnaire (EDE-Q), White Bear Thought Suppression Inventory (WBSI), Sexual Experiences Survey (SES) and Childhood Trauma Questionnaire (CTQ).

\begin{tabular}{llll}
\hline $\begin{array}{l}\text { Matthews-Ewald, } \begin{array}{l}\text { Zulling, \& Ward } \\
(2014)\end{array} \\
\text { Non-experimental, } \\
\text { correlational (EL 4) }\end{array}$ & $\begin{array}{l}\text { Sample from the } \\
\text { American College } \\
\text { Health Association } \\
\text { National College } \\
\text { Health Assessment } \\
(\mathrm{n}=110,412)\end{array}$ & $\begin{array}{l}\text { American College Health Association National } \\
\text { College Health Assessment (ACHA-NCHA). }\end{array}$ \\
\hline $\begin{array}{l}\text { Gonçalves et al., } \\
(2016)\end{array}$ & $\begin{array}{l}\text { Non-experimental, } \\
\text { descriptive, } \\
\text { correlational (EL 4) }\end{array}$ & $\begin{array}{l}177 \text { women with } \\
\text { ED aged 14-38 }\end{array}$ & $\begin{array}{l}\text { Semi-structured interview for the assessment } \\
\text { of risk factor in ED, Eating Disorders } \\
\text { Examination (EDE). }\end{array}$ \\
\hline $\begin{array}{l}\text { Churruca, Ussher, } \\
\text { \& Perz (2016) }\end{array}$ & $\begin{array}{l}\text { Non-experimental, } \\
\text { descriptive, } \\
\text { correlational (EL 4) }\end{array}$ & $\begin{array}{l}15 \text { women with } \\
\text { bulimic behaviours }\end{array}$ & Semi-structured interviews. \\
\end{tabular}

Dunkley, Gorzalka, Non-experimental, 789 female college \& Brotto (2016) descriptive, correlational (EL 4) students aged over 19
Sexual Self-Efficacy Scale for Female Function (SSES-F), Cognitive Distractions During Sexual Activity Scale (CDDAS), Eating Disorders Inventory-3 (EDI-3), Revised Rigid Restraint Scale (RRRS) and Body Shape Questionnaire (BSQ).

\begin{tabular}{|c|c|c|c|}
\hline $\begin{array}{l}\text { Gordon et al., } \\
(2016)\end{array}$ & $\begin{array}{l}\text { Non-experimental, } \\
\text { descriptive, } \\
\text { correlational (EL 4) }\end{array}$ & $\begin{array}{l}21 \text { women aged } \\
19-32\end{array}$ & Interview guide. \\
\hline $\begin{array}{l}\text { Cerniglia et al., } \\
\text { (2016) }\end{array}$ & $\begin{array}{l}\text { Quasi experimental } \\
\text { (EL 3) }\end{array}$ & $\begin{array}{l}202 \text { adolescents } \\
\text { aged } 11-13 \text { and } \\
\text { their parents }(n= \\
202 \text { mothers; } n= \\
202 \text { fathers) }\end{array}$ & $\begin{array}{l}\text { Youth Self-Report (YSR), the Response } \\
\text { Evaluation Measure for Youth (REM-71), } \\
\text { the Toronto Alexithymia Scale (TAS-20), } \\
\text { the Symptom Checklist (SCL-90-R), and the } \\
\text { Traumatic Experience Checklist (TEC). }\end{array}$ \\
\hline $\begin{array}{l}\text { Lampis et al., } \\
\text { (2017) }\end{array}$ & $\begin{array}{l}\text { Non-experimental, } \\
\text { descriptive, } \\
\text { correlational (EL 4) }\end{array}$ & $\begin{array}{l}920 \text { adolescents } \\
\text { aged } 14-21\end{array}$ & $\begin{array}{l}\text { Sociodemographic questionnaire, the Bem } \\
\text { Sex-Role Inventory (BSRI) and the Eating } \\
\text { Disorders Inventory (EDI-2). }\end{array}$ \\
\hline $\begin{array}{l}\text { Mason, Lewis, \& } \\
\text { Heron (2017) }\end{array}$ & $\begin{array}{l}\text { Non-experimental, } \\
\text { descriptive, } \\
\text { correlational (EL 4) }\end{array}$ & $\begin{array}{l}436 \text { homossexual } \\
\text { females aged 18-30 }\end{array}$ & $\begin{array}{l}\text { The SCOFF questionnaire), the Short Positive } \\
\text { and Negative Affect Schedule (S-PANAS), } \\
\text { the State Social Anxiety Questionnaire, } \\
\text { the Multidimensional Scale of Perceived } \\
\text { Social Support (MSPSS) and the Everyday } \\
\text { Discrimination Scale (EDS). }\end{array}$ \\
\hline
\end{tabular}


Table 1.

Characterization of retrieved articles according to authors, year of publication, study design, evidence level (EL), population and measures $(n=19)$. (Continuation)

\begin{tabular}{lll}
\hline Tolosa-Sola et al., & Quasi experimental & 27 women with ED \\
(2017) & (EL 3) & and 24 controls
\end{tabular}

Semi-structured questionnaire to assess psychosexual history and demographic/clinical data, Symptom Checklist Revised (SCL-90-R), Personality Disorder Questionnaire-4 (PDQ4), Eating Disorders Inventory-2 (EDI-2), Eating Attitudes Test-40 (EAT-40), Bulimic Investigatory Test Edinburgh (BITE) and Female Sexual Function.

\begin{tabular}{|c|c|c|c|}
\hline $\begin{array}{l}\text { Watson et al., } \\
\text { (2017) }\end{array}$ & $\begin{array}{l}\text { Quasi experimental, } \\
\text { longitudinal (EL 3) }\end{array}$ & $\begin{array}{l}\text { Data from the } \\
\text { Massachusetts } \\
\text { Youth } \\
\text { Risk Behavior } \\
\text { Survey (MYRB), } \\
\text { from } 1999 \text { to } 2013 \\
\text { (n= 26002) }\end{array}$ & $\begin{array}{l}\text { Massachusetts Youth Risk Behavior Survey } \\
\text { (MYRBS), assessing for age, sex, ethnicity, } \\
\text { sexual orientation, use of diet pills to lose } \\
\text { weight, fasting to lose weight and purging to } \\
\text { lose weight. }\end{array}$ \\
\hline $\begin{array}{l}\text { Zullig, Matthews- } \\
\text { Ewald, \& Valois } \\
\text { (2017) }\end{array}$ & $\begin{array}{l}\text { Non-experimental, } \\
\text { descriptive, } \\
\text { correlational (EL 4) }\end{array}$ & $\begin{array}{l}\text { Data from the } \\
\text { Connecticut Youth } \\
\text { Risk Behavior } \\
\text { Survey was utilized } \\
(\mathrm{n}=2242)\end{array}$ & $\begin{array}{l}\text { Structured questionnaire, developed by } \\
\text { authors. }\end{array}$ \\
\hline
\end{tabular}

and pluralist ideas of gender identity are more in line with the current social scenario.

Cella, Iannaccone and Cotrufo (2013) and Lampis et al., (2017) developed similar studies in which they aimed to investigate possible associations between gender role and eating pathologies. Both studies found that stereotipically feminine traits were linked with high levels of ED symptoms, especially bulimia, drive for thinness and body dissatisfaction. Moreover, adolescents whose gender role was socially considered discrepant from their biological sex were more likely to show higher levels of bulimia and drive for thinness. Lampis et al., (2017) discuss the influence of historical, political, economical and religious context, considering that the binary conceptualization of gender is still strong in Italy, where their study was developed, and contributes to the dissatisfaction with one's own body.

Still considering the impact of social standards on women's eating attitudes and body (dis)satisfaction, Woolhouse et al., (2012) developed a qualitative study that aimed to investigate reports of young women about food, eating, femininity, body and the internalization of traditionally feminine social roles. Thinness was portrayed as a symbol of social, economical and cultural success; restriction and self-denial indicated control, self-discipline, and moral virtue; fat was considered a mark of deviation, absence of self-discipline and something to be "burned" and expurgated; eating was as a source of guilt and shame, and food was sinful and an enemy to be defeated. Accordingly, Green et al., (2008) suggested that women who endorse gender roles traditionally attributed to women, such as dependency and passivity, also present an exacerbated need for social approval. Therefore, these women are at high risk for developing ED.

Results indicated that overvaluation of thinness is the most important factor in the relationship between high compliance with the traditional norms and symptoms of ED. Overall, both studies (Green et al., 2008; Woolhouse et al., 2012) ratify the understanding that restrictive eating and dieting are not individual choices entirely: they are mainly outcomes to neoliberal discourses that overestimate thinness and, as a consequence, segregate women whose bodies do not fit into the norm. Thus, every woman who wishes to feel like they fit in, needs to stay "fit". 
Churruca, Usher and Perz (2016) highlighted the importance of considering the broader role of sociocultural, political and gender issues in explaining ED, along with the attention that has been paid to individual risk factors. Authors aimed to examine constructions of food developed by women with $\mathrm{BN}$, how these constructions relate to cultural discourses and their implications for subjectivity. Results showed six ways in which participants constructed food: "good/healthy" or "bad/unhealthy", "contaminating body and soul", "collapsed into fat", "pleasurable reward", "comfort" and "fuel for the body". Notions of food as comfort and a forbidden pleasure provided two different ways for participants to rationalize their binging: as a form of self-care and medication, or as a disruption to their self-control. Thus, despite women deploying these constructions to make sense of their bulimic behaviours, they are culturally normative, which has implications for therapeutic and preventive strategies for $\mathrm{BN}$.

Yean et al., (2013) and Watson et al., (2017) found an association between male homosexuality, dysfunctional eating behaviours and body dissatisfaction. These results were explained due to the presence of feminine traits in homosexual men, as defined by the BSRI. Hence, masculinity was considered a protective factor against the occurrence of ED. Zullig, Matthews-Ewald and Valois (2017) brought similar results: individuals with high levels of femininity (including homosexual males) showed more restrictive eating behaviours than individuals with high levels of masculinity.

Accordingly, the study developed by Matthews-Ewald, Zulling and Ward (2014) showed that homosexual women - who would present masculine traits (BSRI) - presented few dieting habits, which were not considered dysfunctional eating behaviours, such as vomiting or use of laxatives. However, when compared to heterosexuals, homosexual women were at similar or increased risk for ED (Mason, Lewis, \& Heron, 2017), which can be explained by the existing binary formulation (Lampis et al., 2017) that marginalizes sexual minorities and contributes to their body dissatisfaction. Sexual orientation discrimination was directly associated with disordered eating (Mason, Lewis, \& Heron, 2017).

Finally, the study developed by Gordon et al., (2016) investigated the impact of societal femininity ideals on disordered eating behaviours in transgender women. It is worth emphasizing that "transgender women" comprise "those whose gender identity such as woman, transwoman, Male to Female (MtF), or genderqueer - differs from their assigned male sex at birth" (Gordon et al., 2016, p. 2). This research complies with studies previously presented in this category, since it deals with Western society's constructions about the "ideal female body" and its influence on identity constitution, as well as its relation to symptoms of ED. Findings showed that weight and shape control desires and behaviours were situated at the intersection of four emergent themes: (1) gender socialization and the development of femininity ideals, (2) experiences of stigma and discrimination, (3) biological processes, and (4) multi-level sources of strength and resilience. Sexual objectification, along with stigmatization, was commonly reported by participants and contributed to increase self-objectification and body consciousness. These, in turn, increased psychological strain, body dissatisfaction, and disordered methods of weight control.

The studies included in this category presented, in general, the importance of addressing sexuality, gender identity and gender role in health assistance to better understand the socio-cultural context underlying ED. Studies also associated ED to the culturally and socially imposed ideal of beauty as synonym of personal success for women. This ideal seem to rule attitudes and behaviours of individuals with feminine personality traits, but not individuals with male traits.

Four out of five studies published in 2017 approached the relationship between ED and gender role/sexual orientation, as well as the most recent studies included in this review. This shows that the social reorganization of gender role concepts that has been developed over the last decade (Lampis et al., 2017) has currently been focus of attention in the scientific community, contributing to progresses in the area of sexuality, including dialogues with the ED field.

2. Attitudes towards sexuality, adverse experiences and its relations to ED

This category of analysis includes studies that overall aimed to describe sexual functioning of women with ED and the adverse experiences that may have influenced it. In the study developed by Pinheiro et al., (2010), among the 242 participants, 98\% reported having experienced intimate relationships, and $55 \%$ of these relationships included sexual activities. Approximately $60 \%$ of participants with ED reported libido decrease and anxiety related to sexuality. Women with AN demonstrated higher prevalence of libido decrease than women with BN and with non-specified ED. Lack of sexual activity and libido decrease were associated 
with low body mass index (BMI) throughout life, high levels of interoceptive consciousness and anxiety traits. Sexual anxiety was associated with low BMI, avoidance behaviours and inefficiency. The incidence of sexual dysfunction in women with ED was higher than the normative sample.

Accordingly, Dunkley, Gorzalka and Brotto (2016) developed a study that aimed to explore altered sexuality in relation to disordered eating, emphasizing the role of sexual insecurities. Results indicated that aspects of disordered eating were associated with more cognitive distractions during sexual activity and lower sexual selfefficacy. Measures of disordered eating significantly predicted body and performance-based cognitive distractions during sexual activity, as well as global sexual self-efficacy and all efficacy subscales. Also, women with high risk for ED reported more sexual insecurities compared to women with typical levels of ED risk.

Regarding the relationship between unwanted sexual experiences and ED, Castellini et al., (2013) found that women submitted to Cognitive Behavioural Therapy for AN and BN showed significant improvement in all domains of sexuality, except those who had history of sexual abuse. These participants showed high levels of body image concern at follow-up, which indicates that one's relationship with the body seems to be negatively affected by sexual abuse. Capitaine et al., (2011) also emphasize that negative sexual experiences may have an impact on body image, leading to negative emotions regarding femininity and sexuality, which may precipitate the dysfunctional food restriction. In addition, Tolosa-Sola et al., (2017) uphold that even when controlling for variables including sexual abuse, personality disorder diagnosis and severe depressive symptoms, body dissatisfaction remains associated with sexual impairment among women with ED. Results from these studies indicate that both body and sexual dissatisfaction are inherently related to ED symptoms, and this relation can be strengthened by unwanted sexual experiences.

Two studies assessed mechanisms that women with ED use to cope with the emotional repercussions of sexual abuse: thought suppression (Collins et al., 2014) and non-suicidal self-injury (NSSI) (Gonçalves et al., 2016). Thought suppression involves attempts to remove unwanted thoughts from consciousness. However, participants showed an increase of ED symptoms after suppressing thoughts related to the experience of recent sexual abuse (Collins et al., 2014). Thus, suppressing thoughts from the traumatic experience of abuse resulted in anxieties that were unconsciously headed towards food and body image. Similarly, NSSI in ED patients were associated with purging behaviours, feeling fat and sexual/physical abuse. Authors concluded that ED patients with history of sexual abuse are more likely to engage in maladaptive behaviours as emotion regulation strategies (such as NSSI) when purge symptoms are absent.

Finally, considering possible associations between parental traumatic experiences and the occurrence of ED in the offspring, Cerniglia et al., (2016) investigated psychological functioning of adolescents with BED and their parents. Females showed higher tendency to internalize feelings and emotions, and higher scores on Withdrawal subscale of the Youth SelfReport (YSR). Results also showed that females made use of Somatization and Dissociation, which means that girls with BED usually dissociate from negative emotions using food to numb internal discomfort. Interestingly, mothers of girls with BED also showed higher internalizing symptoms and higher scores on the Depression scale. Regression analysis correlated Depression with higher scores of Withdrawal and Somatization, which suggested links between same-gender dyads (mother-daughter). It is also noteworthy that most of traumatic experiences in mothers resulted from physical and/sexual abuse. This shows that traumatic experiences generate negative psychological reverberations that may persist into the next generation, especially between family members who share the same gender. Several current studies have addressed the issue of psychic transmission among generations of families of members with ED (Leonidas \& Santos, 2015a, 2017; Moura, Santos, \& Ribeiro, 2017; Valdanha-Ornelas \& Santos, 2016).

\section{Conclusions}

The present study aimed to examine current scientific production regarding sexuality-related issues in the context of eating disorders (ED). Therefore, a review was prepared that synthesized the international scientific literature on sexuality of women diagnosed with ED. The results contribute to highlight a growing body of evidence that suggests that the relation between sexuality and eating psychopathology is complex and requires further investigation.

Selected studies overall showed that sexuality and femininity are linked in several ways to the development and maintenance of symptoms of ED. Traditional 
femininity (i. e. normative femininity) was considered a risk factor due to women's efforts to fit into the culturally imposed female stereotype, which proposes that thinness and beauty are synonyms of success in life. On the other hand, masculinity was considered a protective factor against ED. Moreover, despite identifying oneself with feminine or masculine genders, studies indicated that endorsing a gender role that is socially considered discrepant from biological sex (i.e. girls with high levels of masculinity and vice-versa) is related to ED symptomatology.

When it comes to sexuality, gender role issues are central. However, sexual functioning must also be addressed. Eight selected articles showed that women who present greater drive for thinness - which is related to body dissatisfaction, the most important feature of women with ED - presented higher levels of sexual dysfunctions. Authors hypothesized that showing one's body during sexual relations may generate cognitive distractions and discomfort, impairing female sexuality. Thus, body dissatisfaction, drive for thinness and ED are proven to be related variables.

In general, findings indicated that traditional femininity sets an important aetiological factor in the predisposition, onset and maintenance of $\mathrm{ED}$ and should be further approached in future researches. In clinical practice, sexuality-based interventions should be developed and included in protocols of assistance to $\mathrm{ED}$, in order to offer global treatment rather than interventions focused only on specific ED components. It is crucial that these protocols address how women with ED experience femininity and how they perceive their gender role, which is proven to be related to main ED symptoms, such as body dissatisfaction and drive for thinness. Interventions targeting prevention of ED should also include sexuality-related issues by approaching probable negative consequences of adhering to female gender role social requirements, especially those related to weight and body shape.

\section{Limitations of this review}

This review presents several limitations, mostly the lack of randomized controlled trials, which would enable the establishment of possible cause-effect relationships to better understand the association between sexuality and ED. However, sexuality is a multidimensional construct that can be discussed through a wide range of approaches, such as social, psychological, behavioural and biological. Thus, cause-effect relationships should be put in perspective, discussed and articulated along with the subjective and experiential aspects of this construct.

Finally, most of the studies included in this review were based on reductionist conceptions of femininity and masculinity, approaching typical patterns of the normative cisgender phenomena. Therefore, it is worth emphasizing the importance of considering the plurality of the subjective forms of experiencing sexuality.

\section{References}

Alba, P., \& Kes, M. G. (2013). Eating disorders, body image and sexuality. Vertex, 24(110), 285-290.

American Psychiatric Association. (2013). Diagnostic and statistical manual of mental disorders (5th ed.). Arlington, VA: American Psychiatric Publishing.

Braun V., \& Clarke, V. (2006). Using thematic analysis in psychology. Qualitative Research in Psychology, 3(2), 77-101.

Butler, J. (2011). Bodies that matter: On the discursive limits of sex. London: Routledge.

Capitaine, M., Rodgers, R. F., \& Chabrol, H. (2011). Unwanted sexual experiences, depressive symptoms and disordered eating among college students. Eating Behaviors, 12(1), 86-89. DOI: 10.1016/j. eatbeh.2010.11.003.

Carter, J. C., Bewell, C., Blackmore, E., \& Woodside, D. B. (2006). The impact of childhood sexual abuse in anorexia nervosa. Child Abuse \& Neglect, 30(3), 257-269.

Castellini, G., Lo Sauro, C., Lelli, L., Godini, L., Vignozzi, L., Rellini, A. H., Faravelli, C.,Maggi, M., \& Ricca, V. (2013). Childhood sexual abuse moderates the relationship between sexual functioning and eating disorder psychopathology in anorexia nervosa and bulimia nervosa: A 1-year follow-up study. Journal of Sexual Medicine, 10(9), 2190-2200. DOI: 10.1111 /jsm.12232

Cella, S., Iannaccone, M., \& Cotrufo, P. (2013). Influence of gender role orientation (masculinity versus femininity) on body satisfaction and eating attitudes in homosexuals, heterosexuals and transsexuals. Eating and Weight Disorders, 15(2), 115-124. DOI: $10.1007 /$ s40519-013-0017-z

Cerniglia, L. Cimino, S., Ballarotto, G., \& Tambelli, R. (2016). Do parental traumatic experiences have 
a role in the psychological functioning of early adolescents with binge eating disorder? Eating and Weight Disorders, 21(4), 635-644. DOI: 10.1007/ s40519-016-0354-9

Cesnik, V. M. \& Santos, M. A. (2012). Do the physical discomforts from breast cancer treatments affect the sexuality of women who underwent mastectomy?Revista da Escola de Enfermagem da USP, 46(4), 1001-1008. DOI: 10.1590/ S0080-62342012000400031

Churruca, K., Ussher, J. M., \& Perz, J. (2016). Just desserts? Exploring constructions of food in women's experience of bulimia. Qualitative Health Research, 27(10), 1491-1506. DOI: $10.1177 / 1049732316672644$

Collins, B. Fischer, S., Stojek, M., \& Becker, K. (2014). The relationship of thought suppression and recent rape to disordered eating in emerging adulthood. Journal of Adolescence, 37(2), 113-121. DOI: 10.1016/j.adolescence.2013.11.002

Dunkley, C. R., Gorzalka, B. B., \& Brotto, L. A. (2016). Disordered eating and sexual insecurities in young women. The Canadian Journal of Human Sexuality, 25(2), 138-147. DOI: 10.3138/cjhs.252-A6

Eddy, K. T., Novotny, C. M., \& Westen, D. (2004). Sexuality, personality and eating disorders. Eating Disorders, 12(3), 191-208. DOI: 10.1080/10640260490481410

Gagnon, J. H., \& Simon, W. (1973). Sexual conduct: The social sources of buman sexuality. Chicago: Aldine.

Ghizzani, A. \& Montomoli, M. (2015). Anorexia nervosa and sexuality in women: A review. Journal of Sex Education and Therapy, 25(1), 80-88. DOI: 10.1080/01614576.2000.11074332

Gonçalves, S., Machado, B., Silva, C., Crosby, R. D., Lavender, J. M., Cao, L., \& Machado, P. P. (2016). The moderating role of purging behaviour in the relationship between sexual/physical abuse and nonsuicidal injury in eating disorder patients. European Eating Disorders Review, 24(2), 164-168. DOI: 10.1002/erv.2415

Gordon, A. R., Austin, S. B., Krieger, N., White Hughto, J. M., \& Reisner, S. L. (2016). "I have to constantly prove to myself, to people, that I fit the bill": Perspectives on weight and shape control behaviors among low-income, ethnically diverse young transgender women. Social Science and Medicine, 165, 141-149. DOI: 10.1016/j.socscimed.2016.07.038

Green, M. A., Davids, C. M., Skaggs, A. K., Riopel, C. M., \& Hallengren, J. J. (2008). Femininity and eating disorders. Eating Disorders, 16(4), 283-293. DOI: $10.1080 / 10640260802115829$

Hooper, A. \& Dallos, R. (2012). Fathers and daughters: Their relationship and attachment themes in the shadow of an eating disorder. Contemporary Family Therapy, 34(4), 452-467.

Katz-Wise, S. L., Blood, E. A., Milliren, C. E., Calzo, J. P., Richmond, T. K., Gooding, H. C., \& Austin, S. B. (2014). Sexual orientation disparities in BMI among US adolescents and young adults in three race/ethnicity groups. Journal of Obesity, 14, Article ID 547242, 1-8. DOI: 10.1155/2014/537242

Lampis, J., Cataudella, S., Busonera, A., De Simone, S., \& Tommasi, M. (2017). The moderating effect of gender role on the relationships between gender and attitudes about body and eating in a sample of Italian adolescents. Eating and Weight Disorders, 24(1), 3-11. DOI: 10.1007/s40519-017-0372-2

Leonidas, C. \& Santos, M. A. (2015a). Affective and family relationships of women with anorexia and bulimia. Psicologia: Teoria e Pesquisa, 31(2), 181-191. DOI: 10.1590/0102-37722015021711181191

Leonidas, C. \& Santos, M. A. (2015b). Family relations in eating disorders: The Genogram as instrument of assessment. Ciência e Saúde Coletiva, 20(5), 14351447. DOI: $10.1590 / 1413-81232015205.07802014$

Leonidas, C., \& Santos, M. A. (2017). Emotional meanings assigned to eating disorders: Narratives of women with anorexia and bulimia nervosa. Universitas Psychologica, 16(4), 1-13. DOI: 10.11144/ Javeriana.upsy16-4.emae

Lever, J., Frederick, D. A., \& Hertz, R. (2015). Who pays for dates? Following versus challenging gender norms. Journal of Health Psychology. Epub ahead of print November 5. DOI: $10.1177 / 2158244015613107$.

Machado, V., Leonidas, C., \& Santos, M. A. (2012). Psychiatric readmission: An integrative review of the literature. International Nursing Review, 59(4), 447457. DOI: $10.1111 / \mathrm{j} .1466-7657.2012 .01011 . x$

Mason, T. B., Lewis, R. J., \& Heron, K. E. (2017). Indirect pathways connecting sexual orientation and 
weight discrimination to disordered eating among young adult lesbians. Psychology of Sexual Orientation and Gender Diversity, 4(2), 193-204. DOI: 10.1037/ $\operatorname{sgd} 0000220$

Matthews-Ewald, M. R., Zullig, K. J., \& Ward, R. M. (2014). Sexual orientation and disordered eating behaviors among self-identified male and female college students. Eating Behaviors, 15(3), 441-444. DOI: 10.1016/j.eatbeh.2014.05.002

Melnyk, B. M. \& Fineout-Overholt, E. (2005). Evidencebased practice in nursing and healthcare. Philadelphia, PA: Lippincott Williams and Wilkins.

Moher D., Liberati A., Tetzlaff J., \& Altman D. G. The PRISMA Group. (2009). Preferred reporting items for systematic reviews and meta-analyses: The PRISMA statement. Annals of Internal Medicine, 151(4), 221-296. DOI: 10.1371/journal. pmed.1000097

Moura, F. E. G. A., Santos, M. A., \& Ribeiro, R. P. P. (2015). A constituição da relação mãe-filha e o desenvolvimento dos transtornos alimentares. Estudos de Psicologia (Campinas), 32(2), 233-247. DOI: 10.1590/0103-166X2015000200008

Parent, M. C. \& Moradi, B. (2011). An abbreviated tool for assessing feminine norm conformity: psychometric properties of the Conformity to Feminine Norms Inventory-45. Psychological Assessment, 23(4), 958-969. DOI: $10.1037 / \mathrm{a} 0024082$

Pinheiro, A. P., Raney, T. J., Thornton, L. M., Fichter, M. M., Berretini, W. H., Goldman, D., Halmi, K. A., Kaplan, A. S., Strober, M., Treasure, J., Woodside, D. B., Kaye, W. H., \& Bulik, C. M. (2010). Sexual functioning in women with eating disorders. International Journal of Eating Disorders, 43(2), 123-129. DOI: 10.1002/eat.20671

Rosa, B. P., \& Santos, M. A. (2011). Comorbidity of bulimia nervosa with borderline personality disorder: Implications for treatment. Revista Latinoamericana de Psicopatologia Fundamental, 14(2), 268-282.

Sousa, V. D., Driessnack, M., \& Mendes, I. A. C. (2007). An overview of research designs relevant to nursing. Part 1: Quantitative designs. Revista Latino- Americana de Enfermagem, 15(3), 502-507.

Smink, F. R. E., Hoeken, D. V., \& Hoek, H. W. (2013). Epidemiology, course and outcome of eating disorders. Current Opinion, 26(6), 543-548.
Stillwell, S. B., Fineout-Overholt, E., Melnyk, B. M., \& Williamson, K. M. (2010). Evidence-based practice, step by step: Asking the clinical question: A Key step in evidence-based practice. The American Journal of Nursing, 110(3), 58-61. DOI: 10.1097/01. NAJ.0000368959.11129.79

Tolosa-Sola, I., Gunnard, K., Giménez Munieza, C., Casals, L., Grau, A., \& Farré, J. M. (2017). Body dissatisfaction and eating disorder symptomatology: Which factors interfere with sexuality in women with eating disorders? Journal of Health Psychology. Epub ahead of print March 1. DOI: 10.1177/1359105317695425.

Valdanha-Ornelas, E. D., \& Santos, M. A. (2016). Family psychic transmission and Anorexia Nervosa. Psico-USF, 21(3), 635-649. DOI: 10.1590/1413-82712016210316

Watson, R. J., Adijei, J., Saewyc, E., Homma, Y., \& Goodenow, C. (2017). Trends and disparities in disordered eating among heterosexual and sexual minority adolescents. International Journal of Eating Disorders, 50(1), 22-31. DOI: 10.1002/eat.22576

Whittemore, R., \& Knafl, K. (2005). The integrative review: updated methodology. Journal of Advanced Nursing, 52(5), 546-553. DOI: 10.1111/j.1365-2648.2005.03621.x

Wiederman, M. W. (2005). The gendered nature of sexual scripts. The Family Journal, 13(4), 496-502. DOI: $10.1177 / 1066480705278729$

Woertman, L., \& Van den Brink, F. (2012) Body image and female sexual functioning and behavior: A review. Journal of Sex Research, 49(2-3), 184-211.

Woolhouse, M., Day, K., Rickett, B., \& Milnes, K. (2012). "Cos girls aren't supposed to eat like pigs are they?" Young women negotiating gendered discursive constructions of food and eating. Journal of Health Psychology, 17(1):46-56. DOI: 10.1177/1359105311406151

World Health Organization. (2006). Working together for health: The World Health Report. Geneva, Switzerland: WHO Press.

Yean, C., Benau, E. M., Dakanalis, A., Hormes, J. M., Perone, J., \& Timko C. A. (2013). The relationship of sex and sexual orientation on self-esteem, body shape satisfaction, and eating disorder 
symptomatology. Frontiers in Psychology, 4. DOI: 10.3389/fpsyg.2013.00887

Zullig, K. J., Matthews-Ewald, M. R., \& Valois, R. F. (2017). Relationship between disordered eating and self-identified sexual minority youth in a sample of public high school adolescents. Eating and Weight Disorders: Studies on Anorexia, Bulimia and Obesity. 1-9. DOI: 10.1007/s40519-017-0389-6

Recebido em: 09/05/2018 Reformulado em: 12/02/2019

Aceito: 20/02/2019

Acknowledgements:

Authors wish to thank São Paulo Research Foundation (FAPESP) for funding this research through PhD scholarship to the first author (process number 2012/23854-2).

Disclosure:

The authors report no conflicts of interest.

About the authors:

Carolina Leonidas - Assistant Professor at the Psychology Department and the Graduate Program in Psychology of the Universidade Federal do Triângulo Mineiro (UFTM). PhD from the Graduate Program in Psychology at the Faculty of Philosophy, Sciences and Letters of Ribeirão Preto, Universidade de São Paulo (FFCLRP - USP), with a Doctoral stay at King's College London.

ORCID: https://orcid.org/0000-0002-6558-3943

E-mail: carol.leonidas@gmail.com

Manoel Antônio dos Santos - Full Professor at the Psychology Department and the Graduate Program in Psychology of the Faculty of Philosophy, Sciences and Letters of Ribeirão Preto, Universidade de São Paulo (FFCLRP - USP). PhD in Clinical Psychology from the Institute of Psychology at USP - SP.

ORCID: http://orcid.org/0000-0001-8214-7767

E-mail:masantos@fffclrp.usp.br

Contact:

Profa. Dra. Carolina Leonidas

Universidade Federal do Triângulo Mineiro

Instituto de Educação, Letras, Artes, Ciências Humanas e Sociais

Av. Getúlio Guaritá, 159

Uberaba-MG, Brasil

CEP: 38025-440 